\title{
OUTCOMES OF PERCEIVED ONLINE WEBSHOP QUALITY: EMPIRICAL EVIDENCE
}

\section{ISHODI PERCIPIRANE KVALITETE KOJI SE ODNOSE NA ONLINE PRODAVAONICU: EMPIRIJSKI DOKAZI}

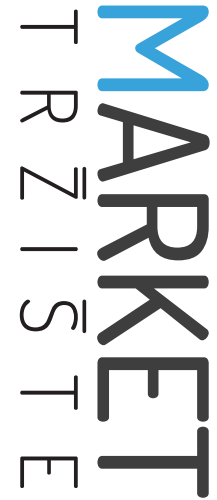

\author{
Market-Tržište \\ Vol. 33, No. 2, 2021, pp. 149-164 \\ UDK 658.62.018.2:658.89:004.738.5:339 \\ D0l http://dx.doi.org/10.22598/mt/2021.33.2.149 \\ Preliminary communication
}

\section{Alexander Joseph Ibnu Wibowo}

Universitas Prasetiya Mulya, School of Business and Economics, BSD City Kavling Edutown I.1, Jl. BSD Raya Utama, BSD City, Kec. Pagedangan, Tangerang, Banten, INDONESIA, e-mail: ibnu.wibowo@pmbs.ac.id

\begin{abstract}
Purpose - Despite tremendous growth of e-commerce, there are reports of concerns about the quality of products and services in online transactions. This study evaluates customer perceptions of product quality in online circumstances. Specifically, the study proposes a model for analyzing the prominent outcomes of perceived webshop quality.
\end{abstract}

Design/Methodology/Approach - The data was obtained through an online survey using a structured questionnaire administered to 515 online customers. Furthermore, regression analyses tested the causal relationship proposed in the hypothesis.

Findings and implications - The study found that both the dimensions of product quality and webshop quality affect customer loyalty and satisfaction. Besides, satisfaction and trust affect loyalty. Results also reveal that satisfaction affects trust. On the other hand, product quality has not been shown to affect customer trust.

Limitations - Since there is no online customer database, a public online survey with screening questions was used. The sample consists only of the representatives of the student population who have purchased products online. As the sample may not reflect the entire population of online consumers worldwide, caution is to be applied when generalizing the findings.

\section{Sažetak}

Svrha - Unatoč ogromnom rastu e-trgovine, postoje izvješća o zabrinutosti u vezi s kvalitetom proizvoda i usluga $u$ online transakcijama. Istraživanje procjenjuje percepcije kupaca o kvaliteti proizvoda u online okolnostima. Konkretno, predlaže se model za analizu istaknutih ishoda percipirane kvalitete.

Metodološki pristup - Podatci su prikupljeni pomoću strukturiranog online anketnog upitnika na uzorku 515 online kupaca. Za testiranje uzročnih odnosa predloženih u hipotezama korištena je regresijska analiza.

Rezultati i implikacije - Istraživanje je pokazalo da obje dimenzije, kvaliteta proizvoda i kvaliteta online prodavaonice, utječu na lojalnost kupaca i zadovoljstvo. Osim toga, zadovoljstvo i povjerenje utječu na lojalnost. Rezultati također otkrivaju da zadovoljstvo utječe na povjerenje. S druge strane, pokazalo se da kvaliteta proizvoda ne utječe na povjerenje kupaca.

Ograničenja - Budući da ne postoji online baza podataka o kupcima, provedeno je javno online istraživanje $s$ eliminacijskim pitanjima. Uzorak je bio samo iz populacije studenata koji su kupili proizvode putem interneta. Stoga je potreban oprez pri generaliziranju nalaza istraživanja. Uzorak možda ne odražava cijelu populaciju online kupaca diljem svijeta.

Doprinos - Istraživanje doprinosi proširenju postojećeg znanja o tome kako se percepcije kvalitete, zadovoljstva i 
Originality - This study contributes the existing knowledge about how perceptions of quality, satisfaction, and trust combine to increase loyalty in the case of e-commerce. This is a step towards expanding and contextualizing research on perceived quality and its outcomes in a non-traditional Eastern context. This paper provides marketers with valuable insights into the perceptions and attitudes of young online shoppers.

Keywords - webshop quality, satisfaction, trust, loyalty, online shopping povjerenja kombiniraju za povećanje lojalnosti u slučaju e-trgovine. To je korak prema proširenju i kontekstualizaciji istraživanja percipirane kvalitete i njezinih ishoda u netradicionalnom istočnjačkom kontekstu. Rad pruža marketinškim stručnjacima vrijedne uvide u percepcije i stavove mladih online kupaca.

Ključne riječi - kvaliteta online prodavaonice, zadovoljstvo, povjerenje, lojalnost, online kupovina 


\section{INTRODUCTION}

Nowadays, advances in ICTs and the advent of Web technology have led to new developments in e-commerce (Hajli, 2015). The advancement of big data and the Internet of things (loT) have brought big changes to e-commerce (Fu et al., 2020). Online retailing is a new phenomenon that is growing rapidly in many countries in the world (Mpinganjira, 2015). Thanks to the advancement of ICT, the current suppliers, manufacturers, and customers must change the ways they conduct business (Choi, Kim, Kim \& Kim, 2006). For example, professionals can take advantage of this progress by using a website to support their marketing strategy (Wang, Law, Guillet, Hung \& Fong, 2015). However, technology readiness acts as a determinant of online shopping attitude (Kaur \& Thakur, 2021). The experience of online shopping during lockdown days has promoted more online shopping (Chen, Zhang, Zhu \& Liu, 2021).

In online shopping, consumer trust and satisfaction with a website affect their eagerness to purchase. Customers prefer trustworthy online shopping malls (Yu \& Han, 2021). Affective trust positively contributes to online shopping wellbeing, but cognitive trust does not (Nghia, Olsen \& Trang, 2020). Website coherence and complexity affect consumer trust and satisfaction with websites (Yeh \& Li, 2014). Layout and functionality affect customer satisfaction and comfort (Ghouri, Tong \& Hussain, 2021). Showrooming has been found to increase online shopping intention specifically concerning product and financial risk (Johnson \& Ramirez, 2021). Product return intention has the greatest impact on online shopping returns (Lin, Lee, Siu, Lau \& Choy, 2020). Likewise, continuous improvement of web-based systems and maintenance of system quality are important for building e-loyalty (Choi et al., 2006). Moreover, the advent and improvement of information and communication technology provide a perspective through which trust in an online milieu may be discussed (Wang et al., 2015). Modifying pri- vacy and security policies can create trust in the customer's memory (Daroch, Nagrath \& Gupta, 2021). Web applications can attract individuals to interact and produce online content to support trust and satisfaction (Hajli, 2015). This also plays a role in fostering online customization ( $\mathrm{Ji}$ ang, Balasubramanian \& Lambert, 2015).

In their 2017 study, Tandon, Kiran, and Sah identified weak relationships in customer satisfaction and factors that influence it. They recommended that these factors be investigated to improve their predictability and validate the model through online retailer case studies. According to Ali (2016), literature has identified several significant conceptualizations related to the quality of websites, for example, information, frameworks, and service quality. He advocated further research combining these ideas to operationalize the quality of websites or webshops. Similarly, Korgaonkar, Petrescu, and Becerra (2014) have suggested the need to consider shopping orientation and other consumer characteristics that can influence their behavior on online auction sites, such as brand loyalty and brand preferences, including emotional influences on consumers who participate in online auctions. Online shopping promotion strategies can affect consumer participation intention (Chen \& Li, 2020). Rubin, Martins, llyuk, and Hildebrand (2020) pointed to consumers who have an abstract mindset when shopping online as being more likely to buy products.

Some researchers suggest that further studies should examine findings regarding online shopping, such as different product categories and types of services (Cheah, Phau \& Liang, 2015; Wang et al., 2015), and the characteristics and consumer culture of different countries (Cheah et al., 2015; Tandon et al. 2017; Vijay, Prashar \& Sahay, 2019; Natarajan, Balasubramanian \& Kasilingam, 2017) or populations to support the generalization of the research results (Chen, Wu, Peng \& Yeh, 2015; Ozen \& Engizek, 2014; Chou, Wang, Wang \& Tang, 2014; Shin, Chung, Oh \& Lee, 2013; Noh, Lee, Kim \& Garrison, 2013). Such generalizability can validate the scale in different contexts or cultural environ- 


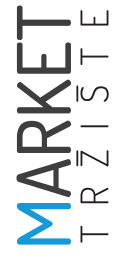

ments (Lee \& Dubinsky, 2017). The incorporation of other consumer demographic characteristics, such as ethnicity, age, and/or geographical location, can shed light on different consumer segments of online behavior (Korgaonkar et al., 2014). Based on the above, this study intends to answer some of the outlined problems by analyzing the effect of online product and webshop quality on the fulfillment, trust, and loyalty of online buyers in the context of Indonesia.

\section{LITERATURE REVIEW AND CONCEPTUAL FRAMEWORK}

\subsection{Perceived quality}

As customers grow more sensitive to price and quality (Moore \& Carpenter, 2006), companies must strengthen the level of product quality by offering a variety of quality products (Choi et al., 2006). When consumers become more understanding of technology, they take a greater part in Internet purchases and have a bigger need for online products or services. Therefore, to entice online customers, online stores should build appropriate websites to fulfill consumers' needs (Wang et al., 2015). Website quality should be addressed from the perspective of customers so that this aspect can play a key role in online transactions (Shin et al., 2013). Many consumers prefer shopping online because they are pressed for time. When consumers shop for products online, they can compare the quality between sites (Shin et al., 2013). Chen, Clifford, and Wells (2002) suggest that e-retailers (i) cause users to feel nice, (ii) make an enjoyable site, (iii) attract consumers to spend a lot of time and revisit, and (iv) increase the likelihood of purchase. Besides, online stores need to fulfill consumer orders on time and protect their privacy (Mpinganjira, 2015). Service quality gives online retailers the chance to distinguish their online retailers in online markets in ways that appeal to consumers (Wang et al., 2015). One way of maintaining the quality of online services is to maintain the quality of the website.

\subsection{Satisfaction}

Oliver (1997) considers satisfaction to be the consumer's accomplishment reaction, defining it as "the summary psychological state resulting from the emotion surrounding disconfirmed expectations is coupled with a consumer's prior feelings about the consumption experience." In a similar vein, Anderson and Srinivasan (2003, p. 125) proved that "satisfaction may be best understood as an ongoing evaluation of the surprise inherent in a product acquisition and/or consumption experience." Satisfaction combines meaning, feeling, and context-oriented components (Fournier \& Mick, 1999). Satisfaction is one of the significant secrets that drive customer retention rates and the growth of long-term online stores (Chen, Ling, Ying \& Meng, 2012). According to Jaiswal, Niraj, and Venugopal (2010), e-satisfaction is "an online customer's pleasant/unpleasant sense of fulfillment/non-fulfillment experienced during past transactions and visits to retailers." In an attempt to determine electronic satisfaction, Anderson and Srinivasan (2003, p. 125) point to customer contentment with respect to a "prior purchasing experience with a given electronic commerce firm."

\subsection{Trust}

Morgan and Hunt (1994) define trust as confidence in the reliability and integrity of transaction partners. It is considered as quite possibly the main essential for online business achievement (Shin et al., 2013; Hajli, 2015). During online shopping, trust can be a notable element to raise purchasing judgments (Connolly \& Bannister, 2008). Trust is still a major problem in most economic and social transactions, especially in online contexts where there may be a lot of uncertainty (Pavlou, 2003). For this reason, before a decision to make an online purchase is made, consumers must consider trust in a system that facilitates transactions (Internet), certain vendors, and other third parties to maintain exchanges (McCole, Ramsey \& Williams, 2010). Through the online situation, e-trust can be de- 
fined as the trust and confidence of customers that their expectations about the online business will be fulfilled (Valvi \& West, 2013). Trust is more important when risk is considered high, as in the case of e-commerce (Mutz, 2005). Besides, e-shoppers' trust can serve to enrich e-vendors' website content. For this reason, online stores need to display more visual designs of products on the website to attract customers to shop and increase customer trust (Yeh \& Li., 2014).

\subsection{Loyalty}

Customer loyalty is very important for a company's success because loyal customers increase profitability (Reichheld, 1996). Oliver (1999) defines loyalty as a thoroughly regarded commitment to repurchasing a favored product later on. In an online climate, customer loyalty, called e-loyalty, alludes to abiding psychological attachment by customers to certain online sellers or providers of service (Cyr, Hassanein, Head \& Ivanov, 2007). In their research, Anderson and Srinivasan (2003) defined e-loyalty as the customer's "favorable attitude towards an electronic business resulting in repeat buying behavior." Furthermore, Srinivasan, Anderson, and Ponnavolu (2002) describe customer loyalty in e-commerce as ideal attitudes towards e-retailers that bring about continued purchasing behavior. Also, Chocarro, Cortiñas, and Villanueva (2015) pointed to electronic loyalty being characterized by profound responsibility to e-channels for gaining products.

\subsection{The impact of perceived quality on customer satisfaction}

E-services quality can affect online customer satisfaction (Yen, Hsu \& Chang, 2013). Information quality and website system quality can have an impact on online customer satisfaction (Alshibly, 2014). Similarly, Shin et al. (2013) found evidence of the connection between website quality and visitor satisfaction. The quality of the site can be seen, among other elements, from site design, information usage, transaction security, payment systems, and customer communication. Sabiote, Frías, and Castañeda (2012) also identified the effect of online perceived quality on online satisfaction. In the context of e-service, a study undertaken by Chaudhry, Zaheer, Rehman, Ali, and Akbar (2011) revealed the effect of the quality of e-banking services on customer satisfaction. Furthermore, Devaraj, Fan, and Kohli (2006) emphasized the impact of time responsiveness, personalization, security, and reliability on online customer satisfaction too. Based on the findings of several studies, as described above, we propose the following hypotheses:

H1. The webshop quality of online shops has a significant positive impact on customer satisfaction.

H2. The product quality of online shops has a significant positive impact on customer satisfaction.

\subsection{The impact of perceived quality on customer trust}

Website quality is a solid predictor of eTrust (Hsiao, Lin, Wang, Lu \& Yu, 2010; Wang et al., 2015). Specifically, Valvi and West (2013) confirmed the effect of web design on e-trust. Similarly, a study by Shin et al. (2013) complements the evidence of the influence of site quality on customer trust through which the site quality is seen, among other elements, from its design, information usefulness, transaction security, payment systems, and customer communication. Rahimnia and Hassanzadeh (2013) also proved the impact of website content (information and design) on e-trust. Furthermore, website quality perceptions have been shown to influence trust in online suppliers (Qureshi, Fang, Ramsey, McCole, Ibbotson \& Compeau, 2009). The presentation of static products on websites (such as two- or three-dimensional images) can affect consumer confidence, as can the presence of mobile products on websites (such as videos) (Ashman \& Vazquez, 2012). Hence, we propose the two following hypotheses: 


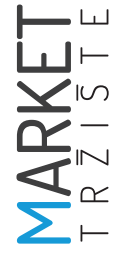

H3. The webshop quality of online shops has a significant positive impact on customer trust.

H4. The product quality of online shops has a significant positive impact on customer trust.

\subsection{The impact of customer satisfaction on trust}

After Shin et al. (2013) pointed to a connection between satisfaction and e-trust, satisfaction has also been found to influence intention to make repeat purchase indirectly through customer trust and commitment. Furthermore, a study conducted by Chung and Shin (2010) of online electronic commerce in South Korea succeeded in proving the impact of online customer satisfaction on e-trust. Other studies finding evidence of the effect of satisfaction on customer trust in an online context include those authored by Rose, Clark, Samouel, and Hair (2012), Ha and Perks (2005), Ha, Janda, and Muthaly (2010), and Kim, Zhao, and Yang (2008). Accordingly, we hypothesize as follows:

H5. Customer satisfaction has a significant positive impact on customer trust.

\subsection{The impact of perceived quality on customer loyalty}

Service quality of online shops (i.e., quality of platforms, quality of interaction, and quality of results) has a significant influence on consumer attitudes towards online stores and behavioral responses in terms of involvement in positive word of mouth (Mpinganjira, 2015). Furthermore, Swaid and Wigand (2009) found evidence that the quality of online services (e-service) affects the loyalty of online customers. Service friendliness has also been shown to influence loyalty (Krasnova, Veltri, Spengler \& Günther, 2013). Likewise, attractiveness and site efficiency affect e-loyalty (Alwi \& Ismail, 2013). The presentation of static products on the website (such as two- or three-dimensional images) can affect consumers' intention to continue buying. Also, the presentation of mobile products on the website (such as video) affects loyalty among consumers (Ashman \& Vazquez, 2012). Based on the previous studies described above, we propose the following hypotheses:

H6. The webshop quality of online shops has a significant positive impact on customer loyalty.

H7. The product quality of online shops has a significant positive impact on customer loyalty.

\subsection{The impact of customer satisfaction on loyalty}

Previous research has found proof of the significance of e-satisfaction on repurchase intention and loyalty (Mpinganjira, 2015; Chou et al., 2014; Vijay et al., 2019), as well as of customer satisfaction with e-banking affecting loyalty (Chaudhry et al., 2011). Yen and Lu (2008) also found the effect of satisfaction on the loyalty intention of online bidders in the context of online auctions. When it comes to distance learning programs (online learning), Udo, Bagchi, and Kirs (2011) asserted that online learner satisfaction influences learners' behavioral intentions, such as the desire to recommend online learning to others. Thus, hypothesize as follows:

H8. Customer satisfaction has a significant positive impact on customer loyalty.

\subsection{The impact of customer trust on loyalty}

Several studies have proven the influence of online customer trust on the intention to continue buying products in an online webshop (Shin et al., 2013; Valvi \& West, 2013). Similarly, customer trust has been shown to influence customer loyalty (Ashman \& Vazquez, 2012; Deb \& Chavali, 2010; Garepasha, Aali, Zendeh \& Iranzadeh, 2021). Furthermore, a study by Hu and Chuang (2012) revealed that the value of trust influences the loyalty intention towards website e-retailers. E-trust affects e-loyalty in U.S. and South Korean cultures (Jin, Yong Park \& Kim, 2008). Besides, 
trust influences loyalty intentions in the context of online shopping platforms (Zheng, Lee \& Cheung, 2017). Therefore, we propose the following hypothesis:

H9. Customer trust has a significant influence on customer loyalty.

\section{RESEARCH METHOD}

\subsection{Data collection and sampling technique}

This research was designed to take place in the form of survey, distributed to students at a private university in Indonesia. Respondents were active students who have purchased products online; they were selected using the convenience sampling method. Data was gathered through anonymous online surveys created through a Google form. Research assistants were hired to survey current respondents who were still enrolled as college students in undergraduate programs. We involved students as respondents for this study considering the advantages of doing so, such as their being in a single location (in class or campus), which facilitated the data collection process. Also, many students, especially those with middle to higher socioeconomic status, were believed to have made online purchases before. The researcher personally invited each student to participate in this research, including a link to the anonymous online survey. Participants were assured complete anonymity. The responses were carefully monitored concerning their number and the pace at which they came in.

A structured questionnaire was employed to obtain data related to online customer evaluation of various types of online shops. The survey asked respondents to assess their experiences with online shops. The majority of questions in the online survey were close-ended questions, providing a set of given answers. We succeeded in obtaining data from 602 respondents, but only data from 515 respondents were considered eligible for further analysis. Thus, 87 ques- tionnaires (14\%) had to be discarded because there were incomplete answers both to the main questions and to those determining the respondents' profiles.

\subsection{Measurements}

The survey instruments are intended to measure the number of constructs examined, such as product and webshop quality, satisfaction, trust, and loyalty. Measurements in the research include giving numbers to empirical events, objects or properties, or activities per established rules (Cooper \& Schindler, 2012). All instruments in this study were adapted and modified from previous studies. The product quality construct was measured using three indicators from Jarvenpaa and Todd (1996). Six indicators for webshop quality were adapted from Parasuraman, Zeithaml, and Berry (1988), Jarvenpaa and Todd (1996), and Zeithaml, Parasuraman, and Malhotra (2000). The dimensions of customer satisfaction were measured using four items adopted from Zeithaml et al. (2000). Four indicators for the construct of customer trust were taken from Ribbink, van Riel, Liljander, and Streukens (2004). Next, the customer loyalty variable was measured using four indicators obtained from Zeithaml et al. (2000). All indicators were measured on a seven-point Likert scale. In addition, the instrument also included aspects of the respondents' profiles, such as study program, gender, domicile (place of residence), and average personal monthly expenses.

\subsection{Validity and reliability}

In this study, construct validity was tested through confirmatory factor analysis (Cooper \& Schindler, 2012) using SPSS 22 statistical software. The internal consistency reliability (homogeneity between items) was assessed using the Cronbach's Alpha coefficient (Cooper \& Schindler, 2012). In addition, descriptive statistical analysis was also applied to obtain the average value and standard deviation of each indicator, including the frequency of each variable. Furthermore, testing of the 11 hypoth- 
eses proposed was done using multiple linear regression. Based on the results of the validity test, all indicators were proven valid so that all indicators were used in subsequent analysis. All of these indicators have a greater factor loading value than 0.5 . In general, the reliability test results also showed positive results (see Table 2).

\section{RESULTS}

\subsection{Respondents' profiles}

Most of the respondents in this study were women (53\%). They were active students at a famous private university in Jakarta, Indonesia, most of whom enrolled in the Business Study Program (68\%) as a major and living in the cities of Jakarta, Bogor, Tangerang, and Bekasi. They were of middle to higher socioeconomic status, with $71 \%$ of the respondents spending around IDR 1-3 million a month on personal items. While the respondents were between 18 and 23 years old, their age was not specified in this study. More information on the profile of the respondents can be found in Table 1.

TABLE 1: Respondents' profile

\begin{tabular}{|l|c|c|}
\hline Descriptions & Number & Percentage \\
\hline Gender \\
\hline Male & 244 & 47 \\
\hline Female & 271 & 53 \\
\hline
\end{tabular}

\section{Study Program:}

\begin{tabular}{|l|c|c|}
\hline Business & 348 & 68 \\
\hline Finance & 53 & 10 \\
\hline Marketing & 75 & 15 \\
\hline Accounting & 35 & 7 \\
\hline No answer & 4 & 1 \\
\hline Residence \\
\hline North Jakarta & 71 & 14 \\
\hline Central Jakarta & 25 & 5 \\
\hline South Jakarta & 71 & 14 \\
\hline West Jakarta & 93 & 18 \\
\hline
\end{tabular}

\begin{tabular}{|l|c|c|}
\hline Descriptions & Number & Percentage \\
\hline East Jakarta & 17 & 3 \\
\hline Bogor & 15 & 3 \\
\hline Tangerang & 171 & 33 \\
\hline Bekasi & 23 & 4 \\
\hline Others & 29 & 6 \\
\hline
\end{tabular}

\section{Average personal monthly expenditures} (in USD):

\begin{tabular}{|l|c|c|}
\hline$<70$ & 40 & 8 \\
\hline $70-140$ & 178 & 35 \\
\hline $140-211$ & 184 & 36 \\
\hline $211-281$ & 56 & 11 \\
\hline $281-351$ & 30 & 6 \\
\hline $351-421$ & 13 & 3 \\
\hline$>421$ & 13 & 3 \\
\hline No answer & 1 & 0.2 \\
\hline
\end{tabular}

\subsection{Descriptive statistics}

Based on the results of descriptive statistical analysis (Table 2), almost all indicators measuring the six constructs averaged more than 5.00. This confirms that all variables showed positive results. Regarding webshop quality, online stores were found to have the ability to perform promised services accurately. In terms of product quality, online stores were also considered to have provided accurate product information. Overall, customers are happy with online shop services. Likewise, online stores are believed to intend to fulfill all promises. Customers are also willing to recommend online stores to others.

\subsection{Hypothesis test}

This study used multiple linear regression to test the eleven hypotheses proposed. The primary consideration of various statistical procedures is the goodness-of-fit. The determination coefficient $\left(R^{2}\right)$ is in common use to calculate the variance of the response variable explained by a predictor variable (Johnson \& Wichern, 1982). In this study, the value is 0.434 for model one, 0.296 for model two, 0.484 for model three, and 0.198 for model four. This shows that around 43 
percent of the variation in satisfaction is defined by the independent variables included in model one. Similarly, about $29 \%$ of the variation in trust is clarified by predictor variables in model two. About $48 \%$ of variations in customer loyalty are explained by predictor variables in model three.
Regression analysis of model one successfully found that webshop quality and product quality significantly affected online customer satisfaction. Webshop quality was found to have the greatest influence $(\beta=0.524 ; t=11.698 ; p<0.01)$, followed by product quality $(\beta=0.183 ; t=4.099$;

TABLE 2: Results of descriptive analysis, validity, and reliability

\begin{tabular}{|c|c|c|c|c|}
\hline Variables & Mean & SD & $\begin{array}{l}\text { Factor } \\
\text { loading }\end{array}$ & $\begin{array}{c}\text { Cronbach's } \\
\text { alpha }\end{array}$ \\
\hline Webshop quality & & & & 0.817 \\
\hline $\begin{array}{l}\text { This online shop guarantees safe transactions to inspire } \\
\text { trust and confidence. }\end{array}$ & 5.46 & 0.986 & 0.784 & \\
\hline $\begin{array}{l}\text { This online shop has the ability to perform promised } \\
\text { services accurately. }\end{array}$ & 5.29 & 0.984 & 0.798 & \\
\hline $\begin{array}{l}\text { This online shop understands my needs and pays } \\
\text { attention to them. }\end{array}$ & 5.08 & 1.033 & 0.745 & \\
\hline It is easy to contact an online shop. & 5.62 & 0.931 & 0.699 & \\
\hline This online shop is interested in feedback. & 5.09 & 1.165 & 0.595 & \\
\hline This online shop responds quickly to customer requests. & 5.18 & 1.081 & 0.735 & \\
\hline Product quality & & & & 0.728 \\
\hline This online shop provides accurate product information. & 5.32 & 1.006 & 0.839 & \\
\hline This online shop provides products at competitive prices. & 5.51 & 0.975 & 0.743 & \\
\hline This online shop provides high quality products. & 5.27 & 1.085 & 0.830 & \\
\hline Customer satisfaction & & & & 0.834 \\
\hline Overall, I am happy with the online shop service. & 5.55 & 1.007 & 0.881 & \\
\hline This online shop's website is easy to use. & 5.63 & 0.938 & 0.718 & \\
\hline I am very satisfied with the online shop service. & 5.32 & 1.011 & 0.866 & \\
\hline I'm happy with the online shop. & 5.35 & 1.066 & 0.799 & \\
\hline Trust & & & & 0.711 \\
\hline $\begin{array}{l}\text { I am willing to provide personal information to the } \\
\text { online shop. }\end{array}$ & 4.87 & 1.300 & 0.740 & \\
\hline $\begin{array}{l}\text { I am willing to provide a credit card number to the } \\
\text { online shop. }\end{array}$ & 3.90 & 1.701 & 0.707 & \\
\hline $\begin{array}{l}\text { I do not mind paying in advance for the purchase of this } \\
\text { online shop's products. }\end{array}$ & 5.04 & 1.211 & 0.763 & \\
\hline Online shop intends to fulfill all its promises. & 5.28 & 1.053 & 0.760 & \\
\hline Customer loyalty & & & & 0.837 \\
\hline I would recommend this online shop to others. & 5.29 & 1.098 & 0.863 & \\
\hline I would recommend this online shop website to others. & 5.25 & 1.044 & 0.851 & \\
\hline I am interested in using the online shop again. & 5.61 & 1.018 & 0.819 & \\
\hline I choose an online shop comparing it to other online shops. & 5.28 & 1.075 & 0.746 & \\
\hline
\end{tabular}


$\mathrm{p}<0.01$ ). Therefore, $\mathrm{H} 1$ and $\mathrm{H} 2$ were accepted. Furthermore, the results of analysis found that webshop quality and satisfaction significantly affected online customer trust. Webshop quality had the greatest contribution $(\beta=0.4 ; t=7.093$; $p<0.01)$, followed by satisfaction $(\beta=0.197 ; \mathrm{t}=$ 3.937; $\mathrm{p}<0.01$ ). Therefore, $\mathrm{H} 3$ and H5 were also accepted. In contrast, product quality was not proven to influence online customer trust ( $\beta=$ -0.006 ; $t=-0.11 ; p>0.05)$, so H4 was rejected. Next, the result proves that webshop quality, product quality, satisfaction, and trust significantly influence e-loyalty. Customer satisfaction was found to have the greatest influence ( $\beta=$ $0.424 ; t=9.723 ; p<0.01)$, followed by webshop quality $(\beta=0.172 ; t=3.381 ; p<0.01)$, product quality $(\beta=0.130 ; t=2.988 ; \rho<0.01)$, and trust $(\beta$ $=0.100 ; \mathrm{t}=2.595 ; \rho=0.01$ ). Therefore, $\mathrm{H6}, \mathrm{H} 7, \mathrm{H} 8$, and $\mathrm{H} 9$ were accepted (see Tables 3 ). variable that determines online customer satisfaction, followed by product quality. This finding supports the findings of previous studies conducted by Yen et al. (2013), Alshibly (2014), Shin et al. (2013), Sabiote et al. (2012), Chaudhry et al. (2011), and Devaraj et al. (2006). Furthermore, the results of the regression prove that online customer satisfaction is the variable that has the greatest role in encouraging customer loyalty. To improve webshop quality, online stores must have employees who can provide the promised service accurately. In addition, employees must respond quickly to customer requests. This can be obtained through intensive experience and training. As online stores need to design a safe and reliable online transaction system, communication channels between online stores and buyers also need to be developed. The availability of contact

TABLE 3: Results of regression analysis

\begin{tabular}{|l|c|c|c|}
\hline Relationships & $\boldsymbol{\beta}$ & $\boldsymbol{t}$ & Conclusions \\
\hline Model 1: & & & \\
\hline Webshop quality $\rightarrow$ Satisfaction $(\mathrm{H} 1)$ & $0.524^{* *}$ & 11.698 & Accepted \\
\hline Product quality $\rightarrow$ Satisfaction $(\mathrm{H} 2)$ & $0.183^{* *}$ & 4.099 & Accepted \\
\hline Model 2: & & & \\
\hline Webshop quality $\rightarrow$ Trust $(\mathrm{H} 3)$ & $0.400^{* *}$ & 7.093 & Accepted \\
\hline Product quality $\rightarrow$ Trust $(\mathrm{H} 4)$ & -0.006 & -0.110 & Rejected \\
\hline Satisfaction $\rightarrow$ Trust $(\mathrm{H} 5)$ & $0.197^{* *}$ & 3.937 & Accepted \\
\hline Model $3:$ & & & \\
\hline Webshop quality $\rightarrow$ Loyalty $(\mathrm{H} 6)$ & $0.172^{* *}$ & 3.381 & Accepted \\
\hline Product quality $\rightarrow$ Loyalty $(\mathrm{H} 7)$ & $0.130^{* *}$ & 2.988 & Accepted \\
\hline Satisfaction $\rightarrow$ Loyalty $(\mathrm{H} 8)$ & $0.424^{* *}$ & 9.723 & Accepted \\
\hline Trust $\rightarrow$ Loyalty $(\mathrm{H} 9)$ & $0.100^{*}$ & 2.595 & Accepted \\
\hline Notes: ${ }^{*} \rho<0.05 ;{ }^{* *} \rho<0.01$ & & & \\
\hline
\end{tabular}

\section{DISCUSSION}

Based on the results of the analysis, we found an important contribution of webshop quality to the outcomes of online-based shopping in Indonesia. The quality of online services is the numbers, for example, supports the creation of two-way communication that can strengthen relationships and trust between online stores and customers. In addition, communication channels are also useful for obtaining customer feedback and supporting the co-production 
or co-innovation processes of online products (services).

This study also found the influence of webshop quality and satisfaction on trust. Webshop quality had the greatest impact, followed by satisfaction. This finding supports the results of previous studies conducted by Hsiao et al. (2010), Wang et al. (2015), Valvi and West (2013), Shin et al. (2013), Rahimnia and Hassanzadeh (2013), Qureshi et al. (2009), Chung et al. (2010), Rose et al. (2012), Ha et al. (2010), Ha and Perks (2005), and Kim et al. (2008). In contrast, this study found no evidence of the connection between product quality and trust, so the findings of the previous study by Ashman and Vazquez (2012) were not supported. We suspect that there are several reasons why product quality does not affect customer trust: (i) customers generally do not physically see the product they want to buy (perception) - this is the main weakness of online shopping. Although online sellers/stores have tried to include narrative information and product photos in a complete, detailed, and interesting manner, this method is still considered to be ineffective in replacing physical observations that are more trusted by customers; (ii) the development of various negative issues surrounding online shopping products, such as cases of product fraud committed by certain online sellers/stores; and (iii) according to Indonesian customers, online shopping cannot replace offline shopping, even among customers of middle to higher socioeconomic status. Offline shopping may still be considered to have an effect on the entertainment sensation which is lacking in online shopping.

This study affirmed the way in which webshop quality, product quality, satisfaction, and trust significantly influence e-loyalty. Customer satisfaction was found to have the greatest influence, followed by webshop quality, product quality, and trust. This finding supports the previous studies conducted by Mpinganjira (2015), Swaid and Wigand (2009), Krasnova et al. (2013), Alwi and Ismail (2013), and Ashman and Vazquez (2012). The finding is also in line with those by
Mpinganjira (2014), Chou et al. (2014), Vijay et al. (2019), Chaudhry et al. (2011), Yen and Lu (2008), Udo et al. (2011), Shin et al. (2013), Valvi and West (2013), Deb and Chavali (2010), Garepasha et al. (2021), Hu and Chuang (2012), Jin et al. (2008), and Zheng et al. (2017). Satisfaction needs to be maintained by providing a pleasant online experience for customers. To do so, online store websites must be designed for the maximum ease of use by customers. Then, even though the quality of the product does not have a direct effect on customer trust, it can indirectly affect customer trust through customer satisfaction. Furthermore, customer trust can be created by keeping all promises to customers. All information on products and services on the website, including promotional programs, is an offer of online store promises to customers. If an online store breaks its promise, the customer trust will decrease. Distrustful customers are not willing to provide personal information to online stores. Finally, customer loyalty is the main reference for online business success. Loyal customers provide many benefits for online stores because they are interested in repeat buying in the future. Even though they are not paid, loyal customers can also act as marketers for online stores because they are willing to recommend products or online store websites to others.

\section{CONCLUSIONS AND FUTURE RESEARCH}

\subsection{Conclusions}

In this empirical research study, all proposed hypotheses were accepted, except $\mathrm{H} 4$, for which no evidence was found of the relationship between product quality and e-trust. Thus, the study identified important contribution of webshop quality to online-based shopping. The quality of online services is the most critical cause of satisfaction. Furthermore, satisfaction has a high impact on loyalty. We conclude that the relationships thatoccur occurring between the three constructs, namely webshop quality, satisfaction, and loyalty, are the most import- 
ant outcomes. The practical implication of this finding is the need for online sellers to give attention to the webshop quality. Online sellers should provide adequate employee training to serve customers accurately, ensure transaction security, and understand customers' needs.

\subsection{Limitation and directions for future research}

Although this study provides various contributions to both the theory and implications on the practical side, its findings must be interpreted with caution given the limitations of the study. Respondents were selected using the convenience sampling method, so the findings are not representative of the entire population. In addition, as the surveys were conducted among students who might not represent the online user population, the generalizability of the conclusions reached is probably limited. Also, the respondents' age was not specified in this study, so it has not been able to describe their profile accurately. Subsequent research needs to focus on specific online shops through a new perspective, i.e., service-dominant logic (Vargo \& Lusch, 2004), in order to explore the core concepts of this perspective, such as resource integration, operant resources, value proposition, institutions, technological innovation, value-in-context, and service ecosystem (Hastari, Adela, Alkhair \& Wibowo, 2020; Scarlett, Reksoprawiro, Amelia \& Wibowo, 2021).

\section{References}

1. Ali, F. (2016). Hotel website quality, perceived flow, customer satisfaction, and purchase intention. Journal of Hospitality and Tourism Technology, 7(2), 213-228.

2. Alshibly, H. H. (2014). A free simulation experiment to examine the effects of social commerce website quality and customer psychological empowerment on customers' satisfaction. Journal of Business Studies Quarterly, 5(4), 21-40.

3. Alwi, S., \& Ismail, S. A. (2013). A framework to attain brand promise in an online setting. Marketing Intelligence and Planning, 31(5), 557-578.

4. Anderson, R. E., \& Srinivasan, S. S. (2003). E-satisfaction and e-loyalty: A contingent framework. Psychology and Marketing, 20(2), 123-138.

5. Ashman, R., \& Vazquez, D. (2012). Simulating attachment to pure-play fashion retailers. International Journal of Retail and Distribution Management, 40(12), 975-996.

6. Chaudhry, N. I., Zaheer, A., Rehman, K., Ali, S. R., \& Akbar, Z. (2011). Antecedents and consequences of subjective disconfirmation in e-service. African Journal of Business Management, 5(10), 3902-3912.

7. Cheah, I., Phau, I., \& Liang, J. (2015). Factors influencing consumers' attitudes and purchase intentions of e-deals. Marketing Intelligence and Planning, 33(5), 763-783.

8. Chen, Q., Clifford, S. J., \& Wells, W. D. (2002). Attitude toward the site II: New information. Journal of Advertising Research, 42(2), 33-45.

9. Chen, C., \& Li, X. (2020). The effect of online shopping festival promotion strategies on consumer participation intention. Industrial Management \& Data Systems, 120(12), 2375-2395.

10. Chen, Z., Ling, K. C., Ying, G. X., \& Meng, T. C. (2012). Antecedents of online customer satisfaction in China. International Business Management, 6(2), 168-175.

11. Chen, Y-C., Wu, J-H., Peng, L., \& Yeh, R. C. (2015). Consumer benefit creation in online group buying: The social capital and platform synergy effect and the mediating role of participation. Electronic Commerce Research and Applications, 14(6), 499-513.

12. Chen, J., Zhang, Y., Zhu, S., \& Liu, L. (2021). Does COVID-19 affect the behavior of buying fresh food? Evidence from Wuhan, China. International Journal of Environmental Research and Public Health, 18(9), 4469. 
13. Chocarro, R., Cortiñas, M., \& Villanueva, M. L. (2015). Customer heterogeneity in the development of e-loyalty. Journal of Research in Interactive Marketing, 9(3), 190-213.

14. Choi, D. H., Kim, C. M., Kim, S-I., \& Kim, S. H. (2006). Customer loyalty and disloyalty in internet retail stores: Its antecedents and its effect on customer price sensitivity. International Journal of Management, 23(4), 925-941.

15. Chou, C-H., Wang, Y-Y., Wang, Y-S., \& Tang, T-I. (2014). Exploring the determinants of repurchase behavior in C2B e-commerce. International Journal of e-Education, e-Business, e-Management and e-Learning, 4(4), 271-282.

16. Chung, K-H., \& Shin, J-I. (2010). The antecedents and consequents of relationship quality in internet shopping. Asia Pacific Journal of Marketing and Logistics, 22(4), 473-491.

17. Connolly, R., \& Bannister, F. (2008). Factors influencing Irish consumers' trust in internet shopping. Management Research News, 31(5), 339-358.

18. Cooper, D. R., \& Schindler, P. S. (2012). Business Research Methods. $11^{\text {th }}$ ed. Boston, MA: McGraw-Hill.

19. Cyr, D., Hassanein, K., Head, M., \& Ivanov, A. (2007). The role of social presence in establishing loyalty in e-service environments. Interacting with Computers, 19(1), 43-56.

20. Daroch, B., Nagrath, G., \& Gupta, A. (2021). A study on factors limiting online shopping behaviour of consumers. Rajagiri Management Journal, 15(1), 39-52.

21. Deb, M., \& Chavali, K. (2010). Significance of trust and loyalty during financial crisis: A study on customer behavior of Indian banks. South Asian Journal of Management, 17(1), 43-60.

22. Devaraj, S., Fan, M., \& Kohli, R. (2006). Examination of online channel preference: Using the structure-conduct-outcome framework. Decision Support Systems, 42(2), 1089-1103.

23. Fournier, S., \& Mick, D. G. (1999). Rediscovering satisfaction. Journal of Marketing, 63(4), 5-23.

24. Fu, H., Manogaran, G., Wu, K., Cao, M., Jiang, S., \& Yang, A. (2020). Intelligent decision-making of online shopping behavior based on internet of things. International Journal of Information Management, 50, 515-525.

25. Garepasha, A., Aali, S., Bafandeh Zendeh, A. R., \& Iranzadeh, S. (2021). Relationship dynamics in customer loyalty to online banking services. Journal of Islamic Marketing, 12(4), 830-863.

26. Ghouri, M. W. A., Tong, L., \& Hussain, M. A. (2021). Does online ratings matter? An integrated framework to explain gratifications needed for continuance shopping intention in Pakistan. Sustainability, 13, 9538.

27. Ha, H-Y., Janda, S., \& Muthaly, S. K. (2010). A new understanding of satisfaction model in e-repurchase situation. European Journal of Marketing, 44(7/8), 997-1016.

28. Ha, H-Y., \& Perks, H. (2005). Effects of consumer perceptions of brand experience on the web: Brand familiarity, satisfaction, and brand trust. Journal of Consumer Behaviour, 4(6), 438-460.

29. Hajli, N. (2015). Social commerce constructs and consumer's intention to buy. International Journal of Information Management, 35(2), 183-191.

30. Hastari, R., Adela, Z., Alkhair, H., \& Wibowo, A. J. I. (2020). Direct and indirect effects of operant resources on co-creation experience: empirical evidence from Airbnb consumers. Business: Theory and Practice, 21(1), 92-103.

31. Hsiao, K-L., Lin, J. C-C., Wang, X-Y., Lu, H-P., \& Yu, H. (2010). Antecedents and consequences of trust in online product recommendations. An empirical study in social shopping. Online Information Review, 34(6), 935-953.

32. Hu, F-L., \& Chuang, C. C. (2012). A study of the relationship between the value perception and loyalty intention toward an e-retailer website. Journal of Internet Banking and Commerce, 17(1), 1-18.

33. Jaiswal, A. K., Niraj, R., \& Venugopal, P. (2010). Context-general and context-specific determinants of online satisfaction and loyalty for commerce and content sites. Journal of Interactive Marketing, 24(3), 222-238. 
34. Jarvenpaa, S. L., \& Todd, P. A. (1996). Consumer reactions to electronic shopping on the world wide web. Journal of Electronic Commerce, 1(2), 59-88.

35. Jiang, P., Balasubramanian, S. K., \& Lambert, Z. V. (2015). Responses to customized products: The consumers' behavioral intentions. Journal of Services Marketing, 29(4), 314-326.

36. Jin, B., Yong Park, J., \& Kim, J. (2008). Cross-cultural examination of the relationships among firm reputation, e-satisfaction, e-trust, and e-loyalty. International Marketing Review, 25(3), 324-337.

37. Johnson, O., \& Ramirez, S. A. (2021). The influence of showrooming on millennial generational cohorts online shopping behavior. International Journal of Retail \& Distribution Management, 49(1), 81-103.

38. Johnson, R. A., \& Wichern, D. W. (1982). Applied Multivariate Statistical Analysis. Englewood Cliffs, NJ: Prentice-Hall.

39. Kaur, A., \& Thakur, P. (2021). Determinants of tier 2 Indian consumer's online shopping attitude: A SEM approach. Asia Pacific Journal of Marketing and Logistics, 33(6), 1309-1338.

40. Kim, C., Zhao, W., \& Yang, K. H. (2008). An empirical study on the integrated framework of e-CRM in online shopping: Evaluating the relationships among perceived value, satisfaction, and trust based on customers' perspectives. Journal of Electronic Commerce in Organizations, 6(3), 1-19.

41. Korgaonkar, P., Petrescu, M., \& Becerra, E. (2014). Shopping orientations and patronage preferences for internet auctions. International Journal of Retail and Distribution Management, 42(5), 352-368.

42. Krasnova, H., Veltri, N. F., Spengler, K., \& Günther, O. (2013). 'Deal of the day' platforms: What drives consumer loyalty?. Business and Information Systems Engineering, 5(3), 165-177.

43. Lee, Y. J., \& Dubinsky, A. J. (2017). Consumers' desire to interact with a salesperson during e-shopping: Development of a scale. International Journal of Retail and Distribution Management, 45(1), 20-39.

44. Lin, D., Lee, C. K. M., Siu, M. K., Lau, H., \& Choy, K. L. (2020). Analysis of customers' return behaviour after online shopping in China using SEM. Industrial Management \& Data Systems, 120(5), 883-902.

45. McCole, P., Ramsey, E., \& Williams, J. (2010). Trust considerations on attitudes towards online purchasing: The moderating effect of privacy and security concerns. Journal of Business Research, 63(9/10), 1018-1024.

46. Moore, M., \& Carpenter, J. (2006). The effect price as a marketplace cue on retail patronage. Journal of Product and Brand Management, 15(4), 265-271.

47. Morgan, R. M., \& Hunt, S. D. (1994). The commitment-trust theory of relationship marketing. Journal of Marketing, 58(3), 20-38.

48. Mpinganjira, M. (2014). Understanding online repeat purchase intentions: A relationship marketing perspective. Management, 19(2), 117-135.

49. Mpinganjira, M. (2015). An investigation of perceived service quality in online shopping: A hierarchical approach. Journal of Applied Business Research, 31(1), 115-129.

50. Mutz, D. C. (2005). Social trust and e-commerce: Experimental evidence for the effects of social trust on individuals' economic behavior. Public Opinion Quarterly, 69(3), 393-416.

51. Natarajan, T., Balasubramanian, S. A., \& Kasilingam, D. L. (2017). Understanding the intention to use mobile shopping applications and its influence on price sensitivity. Journal of Retailing and Consumer Services, 37, 8-22.

52. Nghia, H. T., Olsen, S. O., \& Trang, N. T. (2020). Shopping value, trust, and online shopping well-being: A duality approach. Marketing Intelligence \& Planning, 38(5), 545-558.

53. Noh, M., Lee, K., Kim, S., \& Garrison, G. (2013). Effects of collectivism on actual s-commerce use and the moderating effect of price consciousness. Journal of Electronic Commerce Research, 14(3), 244-260. 
54. Oliver, R. L. (1997). Satisfaction: A behavioral perspective on the consumer. New York, NY: McGraw-Hill.

55. Oliver, R. L. (1999). Whence consumer loyalty?. Journal of Marketing, 63(4), 33-44.

56. Ozen, H., \& Engizek, N. (2014). Shopping online without thinking: Being emotional or rational?. Asia Pacific Journal of Marketing and Logistics, 26(1), 78-93.

57. Parasuraman, A., Zeithaml, V. A., \& Berry, L. L. (1988). SERVQUAL: A multiple-item scale for measuring consumer perceptions of service quality. Journal of Retailing, 64(1), 12-40.

58. Pavlou, P. A. (2003). Consumer acceptance of electronic commerce: Integrating trust and risk with the technology acceptance model. International Journal of Electronic Commerce, 7(3), 101-134.

59. Qureshi, I., Fang, Y., Ramsey, E., McCole, P., Ibbotson, P., \& Compeau, D. (2009). Understanding online customer repurchasing intention and the mediating role of trust - An empirical investigation in two developed countries. European Journal of Information Systems, 18(3), 205-222.

60. Rahimnia, F., \& Hassanzadeh, J. F. (2013). The impact of website content dimension and e-trust on e-marketing effectiveness: The case of Iranian commercial saffron corporations. Information and Management, 50(5), 240-247.

61. Reichheld, F. F. (1996). The loyalty effect: The hidden force behind growth, profits, and lasting value. Boston, MA: Harvard Business School Press.

62. Ribbink, D., van Riel, A. C. R., Liljander, V., \& Streukens, S. (2004). Comfort your online customer: Quality, trust and loyalty on the internet. Managing Service Quality, 14(6), 446-456.

63. Rose, S., Clark, M., Samouel, P., \& Hair, N. (2012). Online customer experience in e-retailing: An empirical model of antecedents and outcomes. Journal of Retailing, 88(2), 308-322.

64. Rubin, D., Martins, C., llyuk, V., \& Hildebrand, D. (2020). Online shopping cart abandonment: A consumer mindset perspective. Journal of Consumer Marketing, 37(5), 487-499.

65. Sabiote, C. M., Frías, D. M., \& Castañeda, J. A. (2012). The moderating effect of uncertainty-avoidance on overall perceived value of a service purchased online. Internet Research, 22(2), 180-198.

66. Scarlett, G., Reksoprawiro, R., Amelia, N., \& Wibowo, A. J. I. (2021). Institutions and technology in the value co-creation process of restaurant consumers: A service-dominant logic perspective. TQM Journal, 3(2), 1754-2731.

67. Shin, J. I., Chung, K. H., Oh, J. S., \& Lee, C. W. (2013). The effect of site quality on repurchase intention in internet shopping through mediating variables: The case of university students in South Korea. International Journal of Information Management, 33(3), 453- 463.

68. Srinivasan, S. S., Anderson, R., \& Ponnavolu, K. (2002). Customer loyalty in e-commerce: An exploration of its antecedents and consequences. Journal of Retailing, 78(1), 41-50.

69. Swaid, S. I., \& Wigand, R. T. (2009). Measuring the quality of e-service: Scale development and initial validation. Journal of Electronic Commerce Research, 10(1), 13-28.

70. Tandon, U., Kiran, R., \& Sah, A. (2017). Analyzing customer satisfaction: Users perspective towards online shopping. Nankai Business Review International, 8(3), 266-288.

71. Udo, G. J., Bagchi, K. K., \& Kirs, P. J. (2011). Using SERVQUAL to assess the quality of e-learning experience. Computers in Human Behavior, 27(3), 1272-1283.

72. Valvi, A. C., \& West, D. C. (2013). E-loyalty is not all about trust, price also matters: Extending expectation-confirmation theory in bookselling websites. Journal of Electronic Commerce Research, 14(1), 99-123.

73. Vargo, S. L., \& Lusch, R. F. (2004). Evolving to a new dominant logic for marketing. Journal of Marketing, 68(1), 1-17.

74. Vijay, T. S., Prashar, S., \& Sahay, V. (2019). The influence of online shopping values and web atmospheric cues on e-loyalty: Mediating role of e-satisfaction. Journal of Theoretical and Applied Electronic Commerce Research, 14(1), 1-15. 
75. Wang, L., Law, R., Guillet, B. D., Hung, K., \& Fong, D. K. C. (2015). Impact of hotel website quality on online booking intentions: eTrust as a mediator. International Journal of Hospitality Management, 47, 108-115.

76. Yeh, Y-S., \& Li, Y-M. (2014). Design-to-lure in the e-shopping environment: A landscape preference approach. Information and Management, 51(8), 995-1004.

77. Yen, C., Hsu, M-H., \& Chang, C-M. (2013). Exploring the online bidder's repurchase intention: A cost and benefit perspective. Information Systems and e-Business Management, 11(2), 211-234.

78. Yen, C-H., \& Lu, H-P. (2008). Effects of e-service quality on loyalty intention: An empirical study in online auction. Managing Service Quality, 18(2), 127-146.

79. Yu, H., \& Han, E. (2021). Developing a measure for online shopping mall reputation (OSMR). Sustainability, 13(7), 3818.

80. Zeithaml, V. A., Parasuraman, A., \& Malhotra, A. (2000). A conceptual framework for understanding e-service quality: Implications for future research and managerial practice. Working Paper, Marketing Science Institute, Cambridge, MA.

81. Zheng, X., Lee, M., \& Cheung, C. M. K. (2017). Examining e-loyalty towards online shopping platforms: The role of coupon proneness and value consciousness. Internet Research, 27(3), 709-726. 